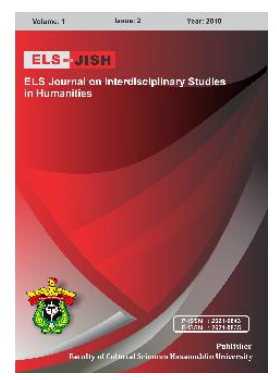

ELS-JISH

ELS Journal on Interdisciplinary Studies on Humanities

Volume 1 Issue 2, 2018

ISSN (print) : 2621-0843

ISSN (online) : 2621-0835

Homepage : http://journal.unhas.ac.id/index.php/jish

\title{
Defense Mechanisms in E. A. Poe's Selected Short Stories the Black Cat \& the Tell-Tale Heart
}

\author{
Rasynal Tenrisanna ${ }^{1}$ \\ e-mail: rasynaltenrisanna@yahoo.co.id
}

\begin{abstract}
Defense mechanism is strategies the ego uses to defend itself against the anxiety provoked by conflicts. The aim of the research is to describe the types of defense mechanism in two of Poe's selected short stories, The Black Cat \& The Tell-Tale Heart \& to reveal the implementation of characters' mechanism in solving the conflicts. The research employed a descriptive qualitative method with a psychoanalysis approach Sigmund Freud's theory of defense mechanism. The data constitute both primary \& supporting data. The primary data derived from E. A. Poe's Selected Short Stories The Black Cat \& The Tell-Tale Heart, while the supporting data were taken by means of library research mainly from books, theses, dissertation, electronic articles \& journals. The results show that the characters have performed a range of defense mechanisms in Poe's selected short stories. In The Black Cat \& The Tell-Tale Heart stories, the characters are mainly concerned with repression, denial, reaction formation, rationalization, displacement of self-defense. These characters performed a range of defense mechanism in order to resolve the conflicts.
\end{abstract}

Keywords: : The Black Cat \& The Tell-Tale Heart, psychoanalysis; defense mechanism

How to cite: Tenrisanna, R. (2018). Defense Mechanisms in E. A. Poe's Selected Short Stories the Black Cat \& the Tell-Tale Heart. ELS Journal on Interdisciplinary Studies in Humanities, 1 (2), 176-183.

\section{Introduction}

Literature is the creation of man as processed in thoughts, feelings \& use of language as a medium. Literature is not just imagination, but it is a result of the author's mind putting into reality with language. Therefore, it is worthy to reflect on literature as a result of human creativity that can be used as a social documentation. Wellek \& Warren (1949), state that literature is a social institution, using as its medium language, a social creation. Such traditional literary devices as symbolism \& meter are social in their very nature. They are conventions \& norm which could have arisen only in society. But, furthermore, literature represent 'life' \& 'life' is in large measure, a social reality, even though the natural world \& the inner or subjective world of the individual have also been objects of literary 'imitatiton'”.

Similarly, Fouzia (2014), defines literature as the mirror of society's views \& believes that reflects social, political \& cultural value of any society \& also reflects people's views, convictions \& dreams in a very creative \& imaginary way to show certain phenomena or to find out a solution to a spesific dilemma. Besides, literature as permanent expressions in words (written or spoken), specially arranged in pleasing accepted patterns or forms.

${ }^{1}$ Politeknik Negeri Media Kreatif 
Literature expresses thoughts, feelings, ideas or other special aspects of human experiences.

As Endraswara (2008), stated that studying psychology literature is similar with studying actual human being from the inside. Studying psychology literature is very beautiful, because we can underst\& the depth of the human soul, clearly very broad \& very deep. Interpretive meaning is widely opened.

Psychoanalysis literature is to explain the unconscious conflicts of authors such as what is revealed in the lives of their childhood. Not all the works of literature could be analyzed through the psychoanalysis approach. It could only be functioned in types of literature that have the psychological elements in it. The Black Cat \& The Tell-Tale Heart are short stories by Edgar Allan Poe that present the characters similarities with the author's own life. The Black Cat \& The Tell-Tale Heart are the examples of literary works with the psychological components dwelling in its contents. Both short stories have similar themes \& the plot of the stories are almost the same. Both stories using unreliable narrators as the main characters, The Black Cat \& The Tell-Tale Heart tell stories about assassination.

Besides, the researcher intends to analyze The Black Cat \& The Tell-Tale Heart by Edgar Allan Poe by using psychoanalysis approach to examine what occured to the characters psyche which were appeared as phenomena portrayed in the short stories. Based on above, these showed that there are some studies that have been previously conducted namely, Stroud (2004), conducted a study entitled Poe's Guinea Pigs: Narrators \& Perversity in Selected Tales. He emphasized on revealing a pattern of though the selected tales as if they are in a series.

Besides, Winastri (2014), conducted a study entitled Psychoanalysis on Edgar Allan Poe's William Wilson, The Black Cat \& Tell-Tale Heart. It shed light on the characterization \& psychoanalysis of three main characters based on their appearances into the short stories. The main characters in these stories were impulsive, imaginative, solicitous, unmanagable, \& a heavy drinker. These stories indicated love \& hate relationship which turned into tragedy.

Similarly, Adhikari (2014), conducted a study entitled Psychology in Crime \& Confession: A Critical Study into Poe's Short Stories The Tell-Tale Heart \& The Black Cat which was merely focused on finding these fundamental issues of psychology, crime \& confession in these two stories as a critical approach to carry out.

Furthermore, Farida (2013), conducted a study entitled Mystery \& Oddity in Edgar Allan Poe's The Tell-Tale Heart. This dissertation studied about the gothic elements; mystry \& oddity in The Tell Tale Heart. In this research, the researcher has applied mystery \& oddity with the influence of psychoanalysis theory that has taken an important part in this story. The researcher can find these gothic elements \& reach the appearance of Freud's theory.

In addition, Hastriyawati (2016), entitled Self-Defense Mechanisms in Eugene O'Neill's Long Day's Journey Into Night. She made an absolute detailed analysis on the types of self-defense mechanisms in drama Long's Day's Journey into Night \& reveal the implementation of characters' mechanisms in solving the conflict. The result of psychoanalysis showed that there were several types of self-defense mechanisms used by the characters in the drama. 
Besides, In Freudian psychology, there are three levels of mental life namely the conscious, the preconscious and the unconscious Alwisol (2009), Feist \& Gregory (2008), tried to begin the explanations of the ego. the researcher will focus on analyzing the defense mechanism in Poe's selected short stories by using Sigmund Freud's theory in Bertens (2006), in which structual theory of personality that is divided into three concepts; id, ego \& superego. Moreover, the researcher will emphasize on the use of defense mechanisms that is also derived from Freud's theory in Schultz \& Schultz (2005), in which this concept covers wide areas of defense mechanisms (repression, denial, reaction formation, rationalization, displacement, sublimation). This research aims to describe of defense mechanisms \& to reveal the implementation of characters' mechanism in solving the conflicts.

\section{Method}

The researcher will use descriptive qualitative method. According to Bogdan \& Biklen in Moleong (1998), the descriptive qualitative method is a research procedure that produces descriptive data in written word or spoken of people \& behaviors that can be observed.

In this research, this method is used to find out defense mehanisms used by the characters in E. A. Poe's Selected Short Stories The Black Cat \& The Tell-Tale Heart.

\subsection{Source of Data}

In collecting data, library research will be used or literature as the main working methods, namely by reading a number of passages that support the object of research \& data analysis to classify two types of data resource namely primary data \& supporting data. This research, the primary data are collected from the texts of the short stories The Black Cat \& The Tell-Tale Heart by Edgar Allan Poe. The supporting data will be used by the researcher are some references that have correlation to the topic of the research, collected from the other sources, such as books, thesis, dissertation, electronic articles, encyclopedia, videos, journals \& dictionaries.

\subsection{Data Collection}

This research is classified as a literary research. Therefore, the correct method used in gathering the data are to search for supporting references through relevant books \& also reliable information from the Internet. A close reading the selected short stories itself, the note-taking method \& highlighting the materials that involves psychology.

\subsection{Data Analysis}

In analyzing the short stories, the researcher will use Freud's psychoanalysis namely personality structure, anxiety \& defense mechanisms. Psychoanalysis is a system or method of psychological theory to analyze a person's psychological condition.

\section{Findings}

Based on the result of the research, In this part, the researcher analyzes the personality structure of characters \& defense mechanisms of the characters in two of $E$. A. Poe's works. 


\subsection{Personality Structure of Characters in The Black Cat \& The Tell-Tale Heart}

In analyzing the characters in those short stories, the researcher explains how the structure of the personality of characters in two of E. A. Poe's selected short stories The Black Cat \& The Tell-Tale Heart.

\section{The id in The Black Cat}

Narrator analogizes his illness like alcohol. He is trying to say the illness to alcohol. Increasingly he felt that this "illness" thrives in his body. There is clearly a depicted man that has as abnormality of mental illness.

As I made no scruple of maltreating the rabbits, the monkey, or event the dog, when by accident, or through affection, they came in my way. But my disease grew upon me --for what disease is like Alcohol ! -- \& at length even Pluto, who was now becoming old, \& consequently somewhat peevish -even Pluto began to experience the effects of my ill temper (Quinn, 1984).

\section{The id in The Tell-Tale Heart}

In the presence of the narrator's illness, instead of eliminating one senses even sharpened his senses. This excerpt, I heard all things in the heaven \& in the earth. I heard many things in hell (Quinn, 1984).

\section{The ego in The Black Cat}

The narrator began the reality testing what occurred at that time toward the poor cat while poke one of its eyes whether the true behavior that hurt the poor cat was making his id impulses are fulfilled.

In the meantime the cat slowly recovered. The socket of the lost eye presented, it is true, a frightful appearance, but he no longer appeared to suffer any pain. He went about the house as usual, but, as might be expected, fled in extreme terror at my approach (Quinn, 1984).

\section{The ego in The Tell-Tale Heart}

TRUE! --nervous --very, very dreadfully nervous I had been \& am; but why will you say that I am mad? The disease had sharpened my senses --not destroyed --not dulled them. Above all was the sense of hearing acute (Quinn, 1984).

The narrator indicates tremendous anxiety, fear \& also anger. The narrator notices any repetition of the word mad shows having the power of emotion of contradiction experienced.

\section{The superego in The Black Cat}

From my infancy I was noted for the docility \& humanity of my disposition (Quinn, 1984).

As indicated in the excerpt above, the narrator has a gentle nature \& have a high humanitarian spirit which means he has learned anything from the environment to form a personality while childhood were taught to show their parents obedience.

\section{The superego in The Tell-Tale Heart}

I loved the old man. He had never wronged me. He had never given me insult. ...l think it was his eye! Yes, it was this ! one of his eyes resembled that of a vulture---a pale blue eye ... "Villains!" I shrieked, "dissemble no more! I admit the deed!---tear up the planks! (Quinn, 1984).

After reading all the text in The Tell-Tale Heart the researcher concludes that these sentences are included as part of the superego, the narrator feels guilty for his behavior that had killed the old man. 


\subsection{Defense Mechanisms of Characters in The Black Cat \& The Tell-Tale Heart}

The types of defense mechanisms that were explained above then the researcher will connect in two of Poe's selected short stories such follows:

\section{Repression in The Black Cat}

The beginning of the narrative, he explains that he did not want to tell everything clearly in the narrative. For him it is a horror story of his life, even though for some of those people maybe his story is nothing compared to the stories of the great barroques.

In their consequences, these events have terrified---have tortured--- have destroyed me. Yet I will not attempt to expound them. To me, they have presented little but horror---to many they will seem less terrible than baroques (Quinn, 1984).

\section{Repression in The Tell-Tale Heart}

In The Tell-Tale Heart, the narrator tried to repress the phobia eye he was afraid the vulture eye including the repression phobia toward anything because of the narrator suppressed things that can cause anxiety out of the area of consciousness.

I think it was his eye! Yes, it was this ! one of his eyes resembled that of a vulture---a pale blue eye, with a film over it. Whenever it fell upon me, my blood ran cold; \& so by degrees---very gradually---I made up my mind to take the life of the old man, \& thus rid myself of the eye for ever (Quinn, 1984).

Denial in The Black Cat, the narrator tried to deny the fact he killed his own cat \& his innocent wife cruelly. The narrator told to reader that he must be crazy whilst any expecting towards his capacity as human beings.

I neither expect nor solicit belief. Mad indeed would I be to expect it, in a case where my very senses reject their own evidence (Quinn, 1984).

\section{Reaction Formation in The Black Cat}

The narrator used the reaction formation so as the beast through that the narrator was still his friend \& had no conflict towards the cat before. The narrator himself was very kind by the cat to the point that he surrounded it with affection.

Pluto---this was the cat's name---was my favorite pet \& playmate.---even Pluto began to experience the effects of my ill temper. One night, returning home, much intoxicated...The fury of a demon instantly possessed me (Quinn, 1984).

\section{Reaction Formation in The Tell-Tale Heart}

The man used the reaction formation so as the old man through that the man was still loved the old man, he had never hurt him \& had no conflict towards the old man before. The man did not know how the idea entered his brain at first that hatred the old man's eye.

I loved the old man. He had never wronged me. He had never given me insult. For his gold I had no desire. I think it was his eye! Yes, it was this ! one of his eyes resembled that of a vulture---(Quinn, 1984).

\section{Rationalization in The Black Cat}

In The Black Cat, the narrator tried to rationalize he is really attempting to narrate the story of his own to the reader. Nevertheless, seeing that his ire of becoming a death row convict, he is exceedingly full of pressure \& all he might resolve to state his wickedness. 
FOR the most wild, yet most homely narrative which I am about to pen, I neither expect nor solicit belief. Mad indeed would I be to expect it, in a case where my very senses reject their own evidence. Yet, mad am I not---\& very surely do I not dream (Quinn, 1984).

\section{Rationalization in The Tell-Tale Heart}

\& now have I not told you that what you mistake for madness is but over acuteness of the sense?--now, I say, there came to my ears a low, dull, quick sound, such as a watch makes when enveloped in cotton. I knew that sound well, too. It was the beating of a drum stimulates the soldier into courage (Quinn, 1984).

This reveals that rationalization does not merely occur to define whose behavior is unacceptable but it may also be utilized by the narrator to define things that he himself could not define plausibly \& in which he himself is convinced by his rationalization.

\section{Displacement in The Black Cat}

The fount for the man's uncontrollable anger in "The Black Cat" was not defined by the man. The researcher merely finds out what caused his extreme change of feeling was alcohol.

Our friendship lasted, in this manner, for several years, during which my general temperament \& character---through the instrumentality of the Fiend Intemperance---had (I blush to confess it) experienced a radical alteration for the worse (Quinn, 1984).

\section{Displacement in The Tell-Tale Heart}

In The Tell-Tale Heart, there is a male who is not labeled on his name in this story. The proof of the narrator's utilization of displacement is the narrator's loathing to the old man's eye.

It is impossible to say how first the idea entered my brain; but once conceived, it haunted me day \& night. ... I think it was his eye! Yes, it was this! one of his eyes resembled that of a vulture---a pale blue eye, with a film over it. Whenever it fell upon me, my blood ran cold; \& so by degrees--very gradually---I made up my mind to take the life of the old man, \& thus rid myself of the eye for ever. (Quinn, 1984).

Sublimation in The Black Cat, the main source of satisfaction is sublimated into the form of keeping pets. He sublimated in the form of keeping animals because it is socially acceptable.

From my infancy I was noted for the docility \& humanity of my disposition. My tenderness of heart was even so conspicuous as to make me the jest of my companions. ... This peculiarity of character grew with my growth, \&, in my manhood, I derived from it one of my principal sources of pleasure. (Quinn, 1984).

\section{Discussion}

The result shows that the researcher describes about the characters' defense mechanisms in two of E. A. Poe's selected short stories \& the character's mechanisms in solving the conflicts.

In the acts of The Black Cat \& The Tell-Tale Heart, the characters used repression, denial, reaction formation, rationalization, displacement, \& sublimation to defend themselves against anxiety \& suspense. Additionally, the characters never used regression.

The researcher thinks that every conflict in The Black Cat \& The Tell-Tale Heart do not answer until the end of the stories because the characters are capable to set their consciousness \& their defense against every conflict. They tend to avoid talking about the 
problem \& use defense mechanisms to solve their conflicts. The researcher had identified there are conflicts in every scene of the stories \& the explanation such follows:

In The Black Cat, this conflict followed from the ego considering that the narrator's wife had not felt such occurring because of an evil black cat. Subsequently the ego was repressed, as the researcher saw in Freud's theory; defense mechanisms such repression that occurs in this first conflict, which was the superstition reverted that led down into unconsciousness denial of the existence of something that causes his narrator wife that had some anxiety about superstition. It can be seen the phrases "allusion to the ancient popular notion, which regarded all black cats as witches in disguise". By satisfying the ego aim to push a sharp to reality, the ego drive ceased yielding within a quieter and showing a balanced state for a while.

In The Tell-Tale Heart, this conflict occurred when the emergence such a strange feeling of discomfort while viewing one of the old man eyes. The narrator describes that he had adored the old man. But the narrator id impulses was unbearable in his mind that the emergence of a deep hatred when viewing one of the old man's eyes. The narrator employs displacement for solving the conflict. The eye only committed as the substitute mark for the old man. Displacement utilized by the narrator was probably caused the narrator was slightly linked towards the old man.

\section{Conclusion}

Based on the existing research results, the researcher can sum up that the types of defense mechanisms of the characters that are found in The Black Cat \& The Tell-Tale Heart. There are six types of defense mechanisms. The defense mechanisms are manageable at every level of characters' unconsciousness, covering: repression, denial, reaction formation, rationalization, displacement \& sublimation. Moreover, there are many types of defense mechanisms for the next researcher to analyze in further studies.

\section{References}

Adhikari K. (2014). Psychology in Crime \& Confession: A Critical Study into Poe's Short Stories The Tell-Tale Heart \& The Black Cat, A Journal of Humanities \& Social Science, ISSN: 2278-5264, accessed on February 14th, 2016. Available from: https://www.thecho.in/files/Kousik-Adhikari--English--.pdf

Alwisol. (2009). Psikologi Kepribadian. Malang: UMM Press.

Bertens K. (2006). Psikoanalisis Sigmund Freud. Jakarta: PT Gramedia Pustaka.

Endraswara S. (2008). Metode Penelitian Psikologi Sastra-Teori, Langkah dan Penerapannya. Yogyakarta: FBS Universitas Negeri Jogjakarta.

Farida A. (2013). Mystery \& Oddity in Edgar Allan Poe's The Tell-Tale Heart. Accessed on January 4th, 2016. Available from: (http://bu.univouargla.dz/master/pdf/abadli farida.pdf?idmemoire $=243$

Feist J. \& Feist J.G. (2008). Theories of Personality Seventh Edition. The United States of America: The McGraw-Hill Companies.

Fouzia D. (2014). Interpretation of the Symbol Black Cat in Edgar Allan Poe's Short Story. accessed on February 17th, 2016. Available from: (http://bu.univouargla.dz/master/pdf/Djaafour-Fouzia.pdf?idmemoire=4315 
Hastriyawati. (2016). Self-Defense Mechanisms In Eugene O'neill's Long Day's Journey Into Night. Unpublished Thesis. Makassar: Post Graduate Program ELS Hasanuddin University.

Moleong L.J. (1998). Metode Penelitian Kualitatif. Bandung: Remaja, Rosdakarya.

Schultz D.P. \& Schultz S.E. (2005). Theories of Personality Eight Edition. The United States of America: Wadsworth.

Stroud M.C. (2004). Poe's Guinea Pigs: Narrators \& Perversity in Selected Tales, accessed on March 5th, 2016. Available from: http://digitalcommons.brockport.edu/cgi/viewcontent.cgi?article=1066\&context=eng t heses

Wellek R. \& Warren A. (1949). Theory of Literature. United States of America: Harcourt, Brace, \& World, Inc.

Winastri N.K.A. (2014). Psychoanalysis on Edgar Allan Poe's William Wilson, The Black Cat \& Tell-Tale Heart, a journal of Non- regular Program, Faculty of Letters. Vol. XVII, No.1, March 2014, accessed on March 6th, 2016. Available from: http://ojs.unud.ac.id/index.php/sastra/article/viewFile/8356/6228 